\title{
TEKANAN INSTITUSIONAL DALAM PRAKTIK TATAKELOLA BADAN USAHA MILIK DESA (BUMDES)
}

\author{
Hafiez Sofyani ${ }^{1}$, Hanif Fahrur Rozi ${ }^{2}$, Firda Ayu Amalia ${ }^{3}$ \\ ${ }^{1,2}$ Fakultas Ekonomi dan Bisnis, Universitas Muhammadiyah Yogyakarta \\ ${ }^{3}$ Fakultas Ekonomi dan Bisnis, Universitas Muhammadiyah Malang \\ hafiez.sofyani@umy.ac.id
}

\begin{abstract}
Many cases of corruption in the Village Owned Enterprises (BUMDes) require good governance implementation to mitigate the potential for corruption or other forms of fraud within the BUMDes entity. While research related to good governance in BUM-Des, there is still minimal access to the day. This study aims to explore the extent to which the practices of good governance principles include: accountability, transparency, responsiveness and community participation have been institutionalized in the management of BUMDes. The research location was conducted in the scope of the Special Region of Yogyakarta involving four BUMDeses. This study uses a descriptive qualitative approach with the method of data collection in the form of interviews with Directors and Staff of BUMDes, village heads, and the community. The results of this study indicate that the implementation of accountability, transparency, responsiveness and community participation in the management of BUMDes in Yogyakarta is more due to normative pressure than coercive or mimetic. Therefore, the implementation of good governance has run quite well even though several indicators of four good governance principles have not yet been fulfilled by some BUMDeses.
\end{abstract}

Keywords: Village-Owned Enterprise (BUMDes); Accountability; Participation; Responsiveness;

Governance; Transparency

\section{Abstrak}

Banyaknya kasus korupsi di entitas Badan Usaha Milik Desa (BUMDes) menuntut adanya implementasi tata kelola yang baik guna memitigasi potensi korupsi atau bentuk kecurangan lainnya di dalam entitas BUMDes. Sementara penelitian terkait tata kelola yang baik di BUMDes, masih minim mendapatkan perhaTian. Penelitian ini bertujuan untuk mengeksplorasi sejauh mana praktik prinsip-prInsip tata kelola yang baik meliputi: akuntabilitas, transparansi, responsivitas serta partisipasi masyarakat telah diinstitusionalisasikan dalam pengelolaan BUMDes. Lokasi penelitian dilakukan di lingkup Daerah Istimewa Yogyakarta dengan melibatkan empat BUMDes. Penelitian ini mengunakan pendekatan kualitatif deskriptif dengan metode koleksi data berupa wawancara kepada Direktur dan Staff BUMDes, kepala Desa, dan masyarakat. Hasil penelitian ini menunjukan Bahwa institutionalisasi akuntabilitas, transparansi, responsivitas dan partisipasi masyarakat dalam pengelolaan BUMDes yang ada di Yogyakrta lebih dikarenakan tekanan normative ketimbang koersif atau mimetik. Karenanya, implementasi tata kelola yang baik talah berjalan cukup baik meskipun beberapa indikator empat prinsip tata kelola yang baik masih belum dipenuhi oleh beberapa BUMDes.

Katakunci: Badan Usaha Milik Desa (BUMDes); Akuntabilitas; Partisipasi; Responsivitas; Tata kelola; Transparansi

Cronicle of Article: Received (September 2020); Revised (November 2020); and Published (December 2020).

(C2020 Jurnal Kajian Akuntansi Lembaga Penelitian Universitas Swadaya Gunung Jati.

Profile and corresponding author: Hafiez Sofyani and Hanif Fahrur Rozi are from Department of Accounting, Faculty of Economics and Business, Universitas Muhammadiyah Yogyakarta. Firda Ayu Amalia is from Department of Accounting, Faculty of Economics and Business, Universitas Muhammadiyah Malang. Corresponding Author: hafiez.sofyani@umy.ac.id

How to cite this article: Sofyani, H., Rozi, H. F., \& Amalia, F. A. (2020). Tekanan Institusional dalam Praktik Tatakelola Badan Usaha Milik Desa (Bumdes). Jurnal Kajian Akuntansi. 4 (2), 111-134. 


\section{PENDAHULUAN}

Insentif merupakan salah satu alternatif Badan Usaha Milik Desa (BUMDes) merupakan salah satu unit bisnis yang dibentuk oleh pemerintah desa (pemdes) dalam rangka menyejahterakan masyarakat desa. Pendirian BUMDes didasarkan atas hak otonomi desa untuk mengoptimalkan potensi yang dimiliki de-sa guna memberdayakan masyarakat desa (Agunggunanto, Arianti, Kushartono, \& Darwanto, 2016). Karakteristik BUMDes yang berdiri di lingkungan masyarakat pedesaan memiliki dua sisi tujuan, yakni sebagai institusi ekonomi dan institusi sosial. BUMDes sebagai institutsi ekonomi maksudnya bahwa didirikaannya BUMDes bertujuan untuk meningkatkan perekonomian masyarakat sehingga BUMDes bersifat profit oriented. Sebagai institusi sosial, BUMDes menjadi lembaga atau wadah yang bergerak dengam melibatkan partisipasi masyarakat (Y. W. SARI, 2017). Keberadaan BUMDes diharapkan dapat mendukung munculnya kembali demokrasi sosial di desa melalui peningkatan kapasitas dan partisipasi masyarakat melalui keterlibatan dalam pengelolaan BUMDes secara berkelanjutan (Ramadana, 2013). Di sisi lain, "BUMDes diharapkan dapat berperan sebagai agen pembangunan daerah dan menjadi pendorong terciptanya sektor korporasi di pedesaan dengan biaya produksi dan pengelolaan tidak terlalu tinggi (Irawati \& Martanti, 2018).

Namun demikian, saat ini telah banyak terjadi kasus manipulasi dan kecurangan dalam pengelolaan keuangan BUMDes. Dilaporkan bahwa Sekertaris desa, bendahara dan ketua salah satu BUMDes di kabupaten Batanghari provinsi Jambi menjadi tersangka karena melakukan penyelewengan dana pembangunan unit usaha BUMDes yang mengakibatkan kerugian Rp. 92 juta rupiah (Aksipost.com, 2019). Sementara itu kasus dugaan korupsi BUMDes telah terjadi di Penajam Paser Utara,
Kalimantan Timur dengan kerugian diperkirakan mencapai Rp 900 juta. Kasus serupa terjadi di Banyumas Raya, kasus yang cukup mencuat di akhir 2018 dimana dilaporkan kasus penyimpangan keuangan yang merugikan keuangan negara $\mathrm{Rp} 1,9$ miliar sehingga ditahannya eks Direktur BUMDes Kecamatan Karangjambu, Kabupaten Purbalingga, yakni M Kahfi sebagai tersangkanya (Satelitpos.com, 2019). Penyelewengan pendapatan BUMDes juga terjadi di kecamatan Karanganyar dimana kerugian yang ditimbulkan selama satu tahun anggaran mencapai 90 juta rupiah (Wawasan.co, 2019).

Untuk mewujudkan cita-cita BUMDes sebagai agen perubahan di desa dan juga memitigasi kecurangan pengelolaan BUMDes, aspek tata kelola yang baik sangat penting untuk diterapkan. Hal ini menjadi alasan kenapa tata kelola pemerintah yang baik (good goverment governance) menjadi isu aktual dalam pengelolaan administrasi publik. Pengelolaan pemerintaha desa, termasuk BUMDes sebagai bagian di dalamnya, dapat dikatakan baik ketika dapat memunculkan iklim akuntabilitas, keterbukaan atau transparansi serta partisipasi yang sesuai dengan prinsip dasar tata kelola yang baik dalam sektor publik (Nainggolan, 2016). Afiah and Rahmatika (2014) menyatakan bahwa aspek utama dari tata kelola pemerintahan yang baik meliputi akuntabilitas, transparansi, dan partisipasi masyarakat. Sementara Pratama and Pambudi (2017) menambahkan pula pentingnya responsivitas sebagai bagian dari tata kelola yang baik. Akan tetapi, berbagai kasus yang disorot di atas mengindikasikan bahwa praktik akuntabilitas dan transparansi di BUMDes masih lemah, sehingga praktik kecurangan berupa korupsi masih marak terjadi. Hal ini menandakan bahwa akuntabilitas, transparansi dan partisipasi masyarakat terhadap pengelolaan BUMDes menjadi aspek yang sangat ur-gent pelaksanaannya. 
Hal ini dikuatkan oleh Khairudin and Erlanda (2016) yang menyatakan bahwa dalam mewujudkan penyelenggaran tata kelola yang baik se-hingga mampu memitigasi praktik korupsi, kolusi, dan nepotisme, asas keterbukaan dimana akuntabilitas, transparansi dan partisipasi masyarakat harus dijalankan secara ideal.

Hingga hari ini, penelitian tentang BUMDes sebenarnya telah beberapa kali dilakukan khususnya pasca ratifikasi UU Desa yang baru. Diantaranya adalah penelitian tatakelola BUMDes yang dilakukan Ramadana (2013) yang meneliti tentang keberadaan BUMDes sebagai penguatan ekonomi desa, Mahmudah (2019) yang meneliti akuntabilitas laporan keuangan BUMDes, Feriady (2019) meneliti business strategic analysis lembaga keuangan mikro berbasis BUMDes dalam rangka penguatan ekonomi desa, Irawati and Martanti (2018) meneliti Transparansi Pengelolaan Laporan Keuangan BUMDes terhadap Pelaporan Aset Desa, dan Kasila and Kolopaking (2018) yang meneliti partisipasi pemuda desa dalam perkembangan usaha BUMDes.

Selanjutnya, penelitian tentang BUMDes juga dilakukan oleh Anggraeni (2017) tentang peran kinerja BUMDes terhadap kesejahteraan masyarakat pedesaan di Gunung Kidul, Hayyuna (2014) mengkaji strategi manajemen aset BUMDes dalam rangka meningkatkan pendapatan desa, Samadi, Rahman, and Afrizal (2015) meneliti peranan BUMDes dalam Peningkatan Ekonomi Masyarakat sesa, R. P. Sari, Rosnita, and Rifai (2014) meneliti analisis kinerja sosial dan kinerja keuangan lembaga keuangan mikro berbasis BUMDes, dan terakhir Sofyani, Atmaja, and Rezki (2019) tentang faktorfaktor yang mendorong tercapainya kinerja BUMDes.

Dari berbagai riset terdahulu yang dipaparkan di atas disimpulkan bahwa riset BUMDes yang fokus menggali aspek tata kelola yang baik masih minim. Ke- banyakan tema dari penelitian BUMDes, sebagaimana disorot diatas, berfokus pada kinerja BUMDes, manfaat keberadaan BUMDes dan strategi bisnis BUMDes. Sementara penelitian terkait tata kelola yang baik penting diakukan untuk mengkaji sejauh mana isu ini telah dijalankan BUMDes karena terkait dengan isu korupsi yang telah disorot di atas.

Secara teoritis, isu institusionalisasi suatu kebijakan di organisasi, dalam kasus ini imlementasi tata keola yang baik di BUMDes, dapat dilihat dari tiga asepk jika merujuk pada konsep isomorfisme institusional model DiMaggio dan Powell (1983). Hawley (dikutip dari DiMaggio dan Powell, 1983) menjelaskan isomorfisme adalah proses munculnya tekanan terhadap satu unit dalam populasi untuk menyerupai unit lain dalam menghadapi pengaturan yang sama dari suatu kondisi lingkungan tertentu. Berangkat dari argument ini, penerapan tata kelola yang baik di BUMDes, bisa jadi merupakan isomorfisme mimetik (imitasi) atau upaya meniru lembaga lain yang dinilai baik pelaksanaan atau mekanisme kerjanya. Selain mimetik, penerapan tata kelola yang baik juga dapat terjadi karena adanya tekanan dari ekster-nal, seperti regulasi, lembaga lain yang lebih tinggi, atau masyarakat sebagai pemangku kepentingan. Isomorfisme yang sifatnya mimetik dan koersif dapat berdampak kurang baik yakni kecender-ungan untuk terjebak pada pelaksanaan suatu mekanisme kerja yang sifatnya se-batas seremonial formil, bukan berorien-tasi pada substansi (Tolbert \& Zucker, 1983). Selian dua jenis isomorfisem di atas, isomorfisme normatif menjadi jenis terakhir dimana adopsi kebijakan di organisasi secara institusional dilatarbelakangi oleh tekanan dari hadirnya orangorang profesional dan komepten.

Adalah fakta di lapangan bahwa pasca banyaknya kasus korupsi di BUMDes, banyak tekanan yang muncul kepada BUMDes untuk menerapkan praktik tata 
kelola yang baik. Hasil observasi awal kami di lapangan menemukan bahwa sebagian besar BUMDes telah melakukan pelaporan keuangan dan kinerja unutk tujuan akuntabilitas, menyelenggarakan musyawarah (partsipasi), serta menyusun Anggaran Dasar dan Anggaran Rumah Tangga (AD/ART) sebagai bentuk supremasi hukum. Namun hingga hari ini, riset yang menggali pelaksanaan prinsipprinsip tata kelola tersebut dari sudut pandang teori institusional khususnya isomorfisme institusional masih sulit ditemukan. Riset semacam ini penting dilakukan untuk mengkonfirmasi motif tekanan yang mendasari pelaksanaan tata kelola yang baik di BUMDes dan selanjutnya menggali dampak yang ditimbulkan Oleh karena itu, secara eksplisit penelitian ini ditujukan untuk menginvestigasi praktik tata kelola yang baik di BUMDes secara lebih mendalam dengan pendekatan kualitatif dari sudut pandang teori isomorfisme institutisional merujuk pada DiMaggio dan Powwel (1983). Secara spesifik studi ini mengeksplorasi sejauh mana dan bagaimana implementasi akuntabilitas, transparansi, responsivitas serta partisipasi masyarakat dalam pengelolan BUMDes telah berjalan.

Secara teoritis penelitian ini memberikan insight terdahap teori insti-tusional "baru" khususnya terkait iso iso-morpisme penerapan tata kelola yang baik di BUMDes dimana literatur yang membahas topik ini masih sangat minim, khususnya yang bersumber dari hasil penelitian empiris. Secara praktis, penelitian ini dapat menjadi rujukan perbaikan kualitas pratik tata kelola yang baik bagi BUMDes lain di Indonesia.

\section{KAJIAN PUSTAKA Landasan Teoritis}

Pada penelitian ini implementasi tata kelola yang baik dikupas dari sudut pandang teori institusional. Menurut DiMaggio and Powell (2000) gagasan utama teori institusional adalah bagaimana organisasi merespon tekanan dari lingkungan institusional yang menyebabkan terjadinya institusionalisasi. Respon tersebut berupa adopsi praktekprekatek serta struktur yang dapat diterima secara sosial sebagai pilihanan organisasional yang tepat dalam rangka memperoleh legitimasi dari konteks institusional mereka.

Teori institusional aliran DiMaggio dan Powell (1983) masuk dalam kategori institusional sosiologis (Thoenig, 2012) yang mempelajari proses difusi yang dicirikan oleh perubahan isomorfik kelembagaan (DiMaggio \& Powell, 1983). Mereka menjabarkan bahwa sebuah inovasi mungkin diadopsi bukan karena hal itu memberikan efisiensi tambahan, melainkan karena adanya mekanisme lain yang sedang bekerja. Lebih jauh, DiMaggio and Powell (1983) menjelaskan bahwa institusionalis dapat terbentuk dari respon organisasi terhadap tekanan dari lingkungan institusional dimana mekanisme pembentukannya dapat karena isomorfisme koersif - hasil perubahan dari tekanan yang diberikan oleh pengaruh politik dan oleh organisasi lain yang dianggap sah, isomorfisme mimetik ketidakpastian dan ambiguitas tentang tujuan atau teknologi meningkatkan adopsi perilaku peniruan - dan isomorfisme normatif - keberadaan para anggota organisasi yang memiliki profesi atau latar belakang yang sama (DiMaggio \& Powell, 1991).

Dibanyak riset akuntansi dan keorganisasian, teori institusional digunakan sebagai penjelasan suatu fenomena dalam lingkungan organisasi sektor publik serta memberikan pandangan yang kompleks. Teori ini menjelaskan tentang tindakan individu dan organisasi dimana keberadaan organisasi dipengaruhi tekanan normatif yang terkadang ditimbulkan dari eksternal seperti lingkungan, namun bisa juga timbul dari dalam organisasi itu sendiri (Meyer \& Rowan, 1977). Dalam konteks institutionalisasi, organisasi 
merespon tekanan dalam bentuk adopsi praktek-praktek serta struktur yang dapat diterima secara sosial sebagai bentuk pilihan organisasional yang tepat (Dwi, 2013). Menurut teori institusional suatu adopsi praktek-praktek yang dapat diterima secara sosial bertujuan agar organisasi memperoleh legitimasi dari konteks institusional mereka (Ahyaruddin \& Akbar, 2018).

Dari gagasan teori institusional di atas, dapat disimpulkan bahwa organisasi terbentuk akibat dipengaruhi oleh lingkungan institusional baik dari internal maupun eksternal di sekitar mereka. BUMDes yang berdiri dalam lingkungan masyarakat pedesaan menjadikan institusi ini memiliki dua sisi sebagai institusi ekonomi dan institusi sosial (Sari, 2017). Sementara praktik tata kelola yang berlaku di BUMDes, akan syarat dengan nilai-nilai masyarakat desa yang cender-ung komunal, gotong-royong, dan mem-iliki tingkat penenerimaan atas aspirasi yang relatif tinggi (Sofyani, Suryanto, Wibowo, \& Widiastuti, 2018).

\section{Social enterprice dan BUMDes}

Secara konsep, BUMDes merupakan bentuk nyata dari gaagsan Social enterprice atau Perusahaan sosial. Berbeda dari sektor swasta, social enterprice lebih berfokus pada pemberian manfaat sosial daripada manfaat finansial. aKarenanya, bagi pemegang saham perusahaan social, fous untuk memfasilitasi kebutuhan masyarakat sosial lebih utama ketimbang orientasi profit (Gibbon \& Affleck, 2008). Namun demikian, SEO (social enterprice organization) juga terlibat dalam bisnis di masyarakat seperti perdagangan, mengambil risiko dan bersaing di pasar dengan organisasi nirlaba. Sementara dari segi pendanaan, tidak seperti bisni swasta, beberapa SEO juga menarik dukungan filantropi dari organisasi dan individu lain khususnya masyarakat desa itu sendiri (Connolly \& Kelly, 2011). Perusahaan sosial dipandang sebagai kekuatan untuk perubahan yang akan berkontribusi pada masyarakat melalui mengatasi tantangan sosial dan lingkungan, dengan menyeimbangkan tanggung jawab keuangan, dampak sosial, dan harus berkoordinasi antara beberapa kelompok pemangku kepentingan termasuk investor (Thompson, 2008).

Menurut Ridley-Duff and Southcombe (2012) karakteristik SEO setidaknya meliputi: 1) Memiliki misi sosial dan/atau lingkungan dalam dokumen hukumnya. 2) Mayoritas pendapatannya didapat dari jual-beli (komersil). 3) Kekuatan pengambilan keputusan tidak didasarkan pada kepemilikan modal. 4) Sifat partisipatif, yang melibatkan orang-orang yang terkena dampak kegiatan. 5) Menginvestasikan ulang mayoritas keuntungannya. 6) Otonom dan independen. 7) Mayoritas dikendalikan oleh kepentingan misi sosial. 8) Bertanggungjawab dan transparan.

\section{Tinjauan Studi Terdahulu}

Ramadana (2013) pada penelitiannya tentang keberadaan BUMDes sebagai penguat ekonomi desa menunjukan hasil faktor permodalan mejadi hal yang paling berpengaruh terhadap pertumbuhan suatu BUMDes di Kabupaten Malang. Ribawanto (2018) menemukan BUMDes menghadapi tantangan dalam modal usaha mandiri yang menyebakan BUMDes masih sangat tergantung dari modal pemerintah. Disisi lain rendahnya produktivitas BUMDes dikarenakan lemahnya sumberdaya manusia di bidang manajemen juga turut menjadi faktor yang mempengaruhi pertumbuhan BUMDes. Samadi et al. (2015) menunjukan kontroling dan pembinaan terhadap penggunaan dana BUMDes dalam orientasi pengembangan Bisnis meningkatkan peran BUMDes dalam peningkatan kemakmuran masyarakat.

Dalam penelitian Irawati and Martanti (2018) tentang Transparansi Pengelolaan Laporan Keuangan BUMDes terhadap Pelaporan Aset Desa, ditemukan pelaporan aset tanah telah menggunakan buku 
"Panduan Data Tanah Desa atau Kelurahan Aset Kabupaten" yang dilaporkan secara tahunan. Namun, laporan akuntabilitas asset tersebut masih kurang sempurna khususnya terkait pelaporan jumlah aset yang dimiliki kantor atau aparatur desa. Sedangkan dalam penelitian Hayyuna (2014) menemukan bahwa manajemen aset desa melalui pengamatan lingkungan, penyusunan strategi, pelaksanaan strategi, evaluasi serta kontrol dapat meningkatkan kinerja sehingga meningkatkan pendapatan Desa. Sementara Kasila and Kolopaking (2018) menemukan bahwa partisipasi terbesar masyarakat dalam pengelolaan BUMDes adalah pada tahap pelaksanaan. Mereka juga menemukan bahwa intensitas komunikasi pengelola BUMDes dan masyarakat menjadi faktor penentu tingkat partisipasi masyarakat. Terakhir, mereka menemukan bahwa tingkat partisipasi masyarakat yang tinggi berkontribusi terhadap perkembangan BUMDes dari segi kelembagaan, kemampuan anggota dan pemasaran produk.

Anggraeni (2017) menemukan bahwa komunikasi dan sosialisasi yang kurang baik oleh pengelola BUMDes menyebakan kurang tersosialiasinya kegiatan dan pelaporan kinerja yang dilakukan BUMDes. Hal tersebut berdampak padatimbulnya rasa kurang percaya dari masyarakat dan menuntut transparansi dan akuntabilitas pengelolaan BUMDes. Dalam penelitian Mahmudah (2019) ditemukan bahwa BUMDes memiliki laporan keuangan yang masih sederhana berupa catatan pengeluaran dan pemasukan, dan tidak ada laporan keuangan konsolidasi yang sesuai dengan standar pelaporan keuangan berterima umum (PABU). Sedangkan dalam penelitian Sari et al. (2014) ditemukan bahwa BUMDes telah mencapai kinerja sosial yang baik dimana misi dan tujuan sosial mengalami peningkatan serta aktivitas dan sistem internal berkembang dengan baik. Sedangkan dalam kinerja keuangan dikategorikan berjalan dengan baik ditunjukan dari indikator PEARLS yaitu protection, effective finacial structure, asset quality, rate of return and cost, liquidity dan sign of growth yang baik.

Selanjutnya, Feriady (2019) menemukan bahwa strategi bisnis yang menjadi keunggulan BUMDes adalah memiliki budaya organisasi yang bersifat kekeluargaan. Sofyani et al. (2019) menemukan faktor-faktor yang mendorong kinerja BUMDes adalah patriotisme dan semangat, keterampilan, pelatihan, tingkat pendidikan, pengalaman, kejujuran (perilaku etis) karyawan BUMDes, tanggung jawab, ketulusan, keseriusan, kepedulian terhadap lingkungan dan masyarakat yang ulet, kekompakan kerja tim, komunikasi yang transparan antara manajer BUMDes, sikap pantang menyerah dalam upaya mencapai target kinerja, religiusitas, kepuasan kerja, gaya kepemimpinan visioner (transformasional), dan kehadiran mekanisme insentif.

Dari banyak penelitian terdahulu yang telah dilakukan dapat disimpulkan bahwa penelitian BUMDes dari aspek good governance masih relatif minim. Karenanya, untuk menutupi celah tersebut penelitian ini bertujuan untuk menggali secara mendalam praktik tata kelola yang baik di BUMDes, yang secara spesifik mengeksplorasi bagaimana implementasi akuntabilitas, transparansi, responsivitas serta partisipasi masyarakat.

\section{METODE PENELITIAN}

Subjek penelitian ini adalah BUMDes yang berada di Daerah Istimewa Yogyakarta. Pemilihan subjek penelitian dilakukan dengan Teknik cluster sampling. Oleh karena itu sampel BUMDes dipilih berdasarkan grade BUMDes yang diambil dari data yang dikeluarkan oleh Biro Bina Pemberdayaan Masyarakat PEMDA DIY 2019. Ada empat badan usaha milik desa yang dipilih sebagai objek penelitian yaitu BUMDes A sebagai 
kategori A (maju), BUMDes B sebagai kategori B (berkembang), BUMDes C sebagai kategori B (berkembang) dan BUMDes D sebagai kategori C (tumbuh). Cluster sampling ditujukan agar dapat ditemukan variasi temuan dari BUMDes dengan grade yang berbeda.

Penelitian ini dilakukan menggunakan metode kualitatif dengan penelitian bersifat deskriptif eksploratif yaitu metode penelitian yang digunakan untuk meneliti dalam kondisi alamiah subjek yang menghasilkan data deskriptif berupa kata- kata tertulis atau lisan dari individu dan perilaku yang diamati (Zikmund, Babin, Carr, \& Griffin, 2013). Sehubung dengan hal ini maka penelitian kualitiatif dianggap tepat digunakan untuk menggambarkan suatu keadaan atau fenomena secara jelas mengenai bagaimana penerapan dan implementasi akuntanbilitas keuangan, transparansi, responsivitas dan partisipasi masyarakat dalam pengelolaan BUMDes (Sekaran \& Bougie, 2016; Smith, 2019). Gambar 1 menyajikan kerangka pemikiran penelitian ini.

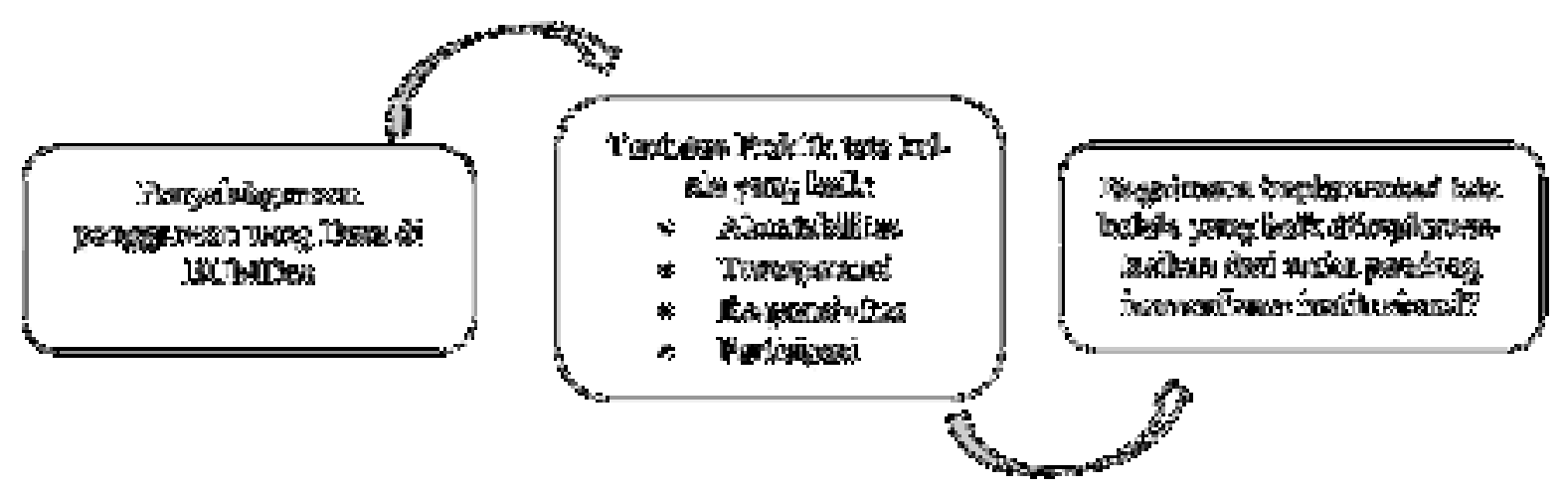

Gambar 1. Kerangka Pemikiran Penelitian

Pendekatan yang digunakan adalah studi multi-kasus. Merujuk Baxter and Jack (2008), dengan menggunakan penelitian multi-kasus dimungkinkan ditemukannya persamaan atau perbedaan implementasi akuntabilitas, transparansi, responsivitas dan partisipasi masyarakat dalam pengelolaan BUMDes dengan kategori klasifikasi BUMDes A (maju), B (berkembang) dan C (tumbuh).

\section{Jenis dan sumber data}

Jenis data dalam penelitian ini adalah data primer dimana data diperoleh langsung dan diolah sendiri oleh peneliti langsung dari subjek penelitian Suyitno (2018). Data primer diperoleh dari wawancara mendalam tatap muka yang dilakukan langsung kepada pihak yang menjadi informan kunci, yakni terlibat dalam pengelolaan Badan usaha milik desa. Informan penelitian ini terdiri dari Kepala desa, manajer, dan staff BUMDes yang diteliti. Dengan demikian, informan yang dipilih benar-benar memiliki infor-masi yang meyakinkan, relevan dan diper-lukan dalam rangka menjawab pertanyaan masalah penelitian ini. Informan yang dilibatkan juga memiliki peran yang berbeda di BUMDes. Dengan demikian maka tingkat dapat dilakukan crosschecking atas data yang diperoleh dari satu informan dengan informan lain. Informan yang dipilih. Dengan demikian, total informan adalah 12. Menurut Francis et al. (2010), ukuran sampel dalam penyelidikan kualitatif harus ditentukan oleh saturasi data, yang umumnya dicapai setelah sepuluh wawancara.

Teknik pengumpulan dan analisis data Teknik pengumpulan data yang digunakan adalah dengan metode wawancara semi terstruktur, dimana peneliti telah menyiapkan daftar pertanyaan yang akan diajukan kepada infroman. Wawancara adalah Suatu kegiatan dilakukan untuk mendapatkan informasi secara langsung 
dengan mengungkapkan pertanyaanpertanyaan pada para responden. wawancara bermakna berhadapan langsung antara interview dengan responden, dan kegiatannya dilakukan secara lisan (Sekaran \& Bougie, 2013).

Semua informan yang diwawancarai diberi pengarahan tentang anonimitas yang dijamin. Ini bertujuan untuk membuat informan merasa bebas dalam mengungkapkan semua informasi yang akan ditanyakan (Zikmund et al., 2013). Penulis akan mencatat beberapa informasi penting untuk mendukung proses analisis. Wawancara dilakukan dengan pertanyaan terbuka dan juga menggunakan alat perekam untuk semakin memudahkan penulis dalam penulisan hasil wawancara karena akan diperoleh data yang lebih akurat dan dapat lebih mudah dalam memasukkannya ke laporan hasil penelitian. Transkripsi dilakukan segera setelah interview dilakukan untuk memastikan semua konteks dan pembicaraan dalam wawancara masih diingat oleh peneliti (Sofyani, Akbar, \& Ferrer, 2018).

Data penelitian dianalisis menggunakan pendekatan interpretatif secara naratif. Following Miles and Huberman (1992), three main activities were conducted in analyzing the transcribed data from the qualitative interviews: data reduction, data display, and conclusion drawing/ verification. peneliti menilai bagaimana implementasi prinsip-prinsip tata kelola yang baik di BUMDes telah dijalankan. Penarikan kesimpulan berupa klasifikasi implmentasi tata kelola dengan kategori : Baik, cukup baik, kurang baik didasarkan pada tingkat impelementasi indikator tata kelola.

Selanjutnya, dengan melakukan analisis yang lebih mendalam melalui proses penkodean, hasil wawancara dikaitkan dengan tema atau masalah penelitian yang sedang dibahas. Interpretasi data dilakukan melalui deskripsi hasil. Untuk memastikan reliabilitas dan validitas data yang dikumpulkan, peneliti melakukan beberapa prosedur seperti pengecekan ulang hasil transkripsi dengan tujuan untuk memastikan tidak ada kesalahan yang dilakukan selama proses transkripsi dan pembekalan dengan sesama peneliti (peer de-briefing) hingga meningkatkan akurasi hasil penelitian (Creswell, 2012).

\section{Definisi dan Indikator Variabel}

Definisi dan Indikator Variabel penelitian yang menjadi rujukan peneliti dalam mengkaji prinsip tata kelola yang baik di BUMDes serta pertanyaan wa-wancara disajikan pada Tabel 1. Merujuk Cooper and Schindler (2014), untuk mendapatkan wawasan yang mendalam dan terperinci, penulis memecahkan empat variabel yang dianalisis menjadi 24 pertanyaan (Tabel 1). Sebelum melakukan wawancara lapangan penulis melakukan pilot study untuk menguji bahwa semua pertanyaan mudah dimengerti dan dapat menangkap semua data informasi yang diperlukan untuk menjawab semua pertanyaan penelitian, sehingga dapat mencapai tujuan penelitian yang ditetapkan

Tabel 1. Definisi dan Indikator Variabel, Pertanyaan Wawancara, dan Target Informan

\begin{tabular}{|c|c|c|c|c|}
\hline No & Variabel & Indikator & Pertanyaan & Informan \\
\hline 1 & $\begin{array}{l}\text { Akuntabilitas } \\
\text { (Ridlwan, 2014) }\end{array}$ & $\begin{array}{l}\text { 1. Ada laporan } \\
\text { pertanggungjawaban yang } \\
\text { disampaikan kepada } \\
\text { masyarakat } \\
\text { 2. Laporan } \\
\text { pertanggungjawaban } \\
\text { memuat: } \\
\text { a. Laporan Kinerja } \\
\text { Pengelola selama satu } \\
\text { periode/tahun. } \\
\text { b. Kinerja yang }\end{array}$ & $\begin{array}{l}\text { 1. Bagaimana mekanisme } \\
\text { laporan pertanggungjawaban } \\
\text { BUMDes dilakukan?. } \\
\text { 2. Apakah ada standar pelaporan } \\
\text { pertanggungjawaban } \\
\text { penggunaan keuangan dan } \\
\text { kinerja? } \\
\text { 3. Bagaimana proses } \\
\text { pengambilan keputusan } \\
\text { dilakukan?Apakah merujuk } \\
\text { kepada laporan tahun lalu? }\end{array}$ & $\begin{array}{c}\text { Kades, } \\
\text { manajer/staff }\end{array}$ \\
\hline
\end{tabular}


Jurnal Kajian Akuntansi, Vol. 4 No. 2 2020, 111-134

e2579-9991, p2579-9975

http://jurnal.ugj.ac.id/index.php/jka

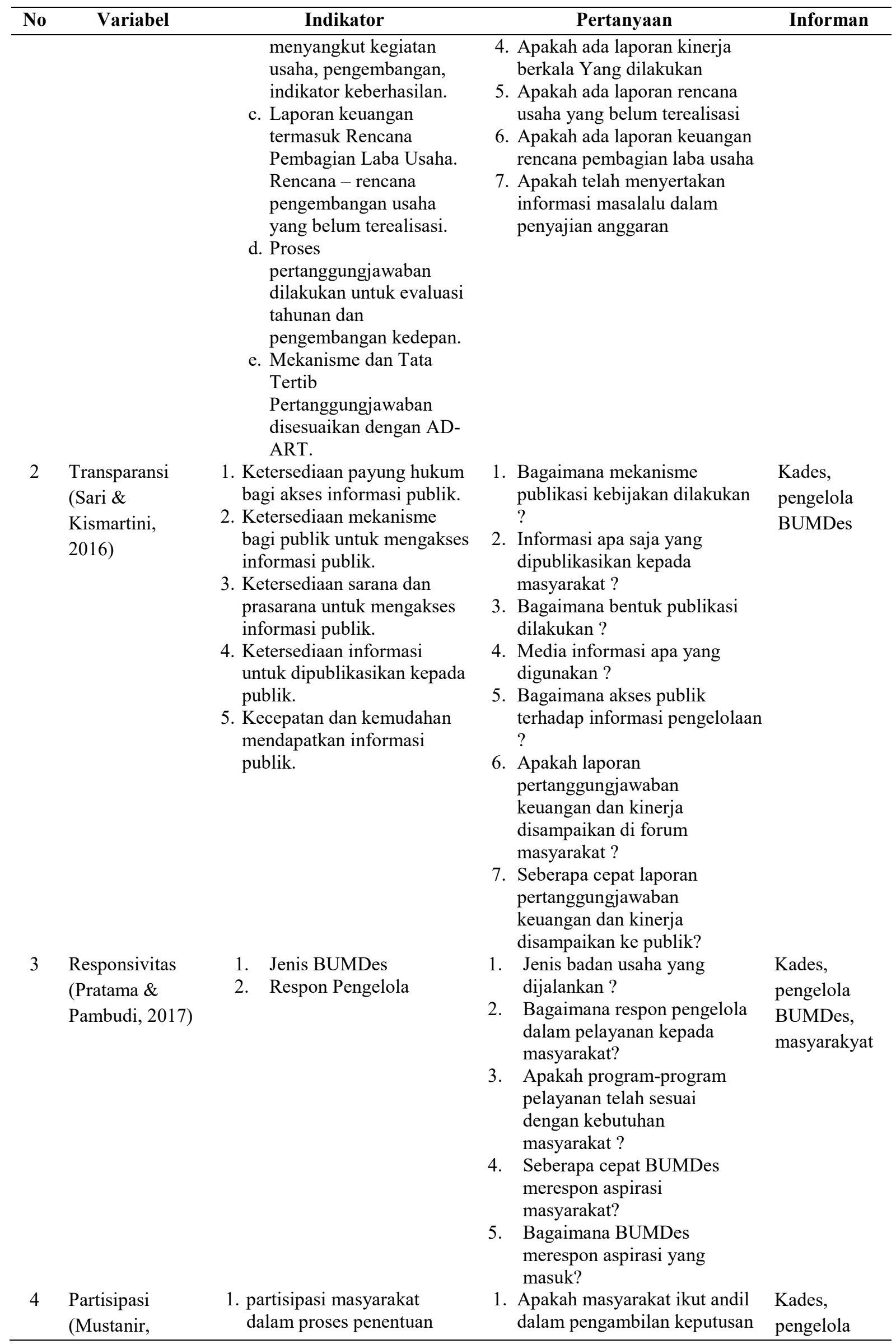


Hafiez Sofyani, Hanif Fahrur Rozi, Firda Ayu Amalia

Tekanan Institutional dalam Praktik Tatakelola Badan Usaha Milik Desa (Bumdes)

\begin{tabular}{|c|c|c|c|c|}
\hline No & Variabel & Indikator & Pertanyaan & Informan \\
\hline & 2017) & $\begin{array}{l}\text { arah dan strategi dan dan } \\
\text { kebijakan dalam } \\
\text { pengelolaan } \\
\text { 2. partisipasi masyarakat } \\
\text { dalam memikul beban dan } \\
\text { tanggungjawab dalam } \\
\text { kegiatan. } \\
\text { 3. partisipasi masyarakat } \\
\text { dalam penentuan arah } \\
\text { strategis dan kebijakan. } \\
\text { 4. partisipasi dan keterlibatan } \\
\text { masyarakat dalam menerima } \\
\text { manfaat. }\end{array}$ & $\begin{array}{l}\text { ? } \\
\text { 2. Apakah masyarakat dilibatkan } \\
\text { dalang pengelolaan? } \\
\text { 3. Bagaimana bentuk } \\
\text { keterlibatan masyarakat dalam } \\
\text { pengelolaan? } \\
\text { 4. Apakah seluruh staff yang } \\
\text { bekerja disini didominasi oleh } \\
\text { masyarakat setempat? } \\
\text { 5. Apakah masyarakat } \\
\text { merasakan manfaat } \\
\text { keberadaan BUMDes? }\end{array}$ & $\begin{array}{l}\text { BUMDes, } \\
\text { masyarakyat }\end{array}$ \\
\hline
\end{tabular}

\section{HASIL PENELITIAN}

Tabel 2 menyajikan kode kutipan percakapan informan dalam transkrip wawancara yang betujuan agar memudahkan pembaca untuk mengidentifikasi dari mana sumber kutipan wawancara berasal.

\section{Implementasi Akuntabilitas BUMDes}

Dalam mengukur Akuntabilitas BUMDes, indikator yang digunakan merujuk pada penelitian Ridlwan (2014) yang meliputi ketersediaan laporan keuangan, laporan kinerja pengelolaan berkala, laporan kinerja usaha, laporan pembagian laba, standar laporan pertanggungjawaban, serta evaluasi. Hasil identifikasi indikatorindikator implementasi BUMDes disajikan pada Tabel 3. Dapat dilihat secara umum implementasi akuntabilitas pada empat BUMDes yang diteliti sudah berjalan cukup baik. Indikator akuntabilitas berupa laporan keuangan dan laporan rencana pembagian laba telah dijalankan diseluruh BUMDes. Disamping itu laporan kinerja berkala, laporan kinerja usaha, serta standar laporan pertanggungjawaban telah dijalankan oleh hampir semua BUMDes. Walau demikian ada BUMDes yang belum menjalakan Prinsip akuntabilitas dengan baik.

Tabel 2. Format Coding Transkrip Wawancara

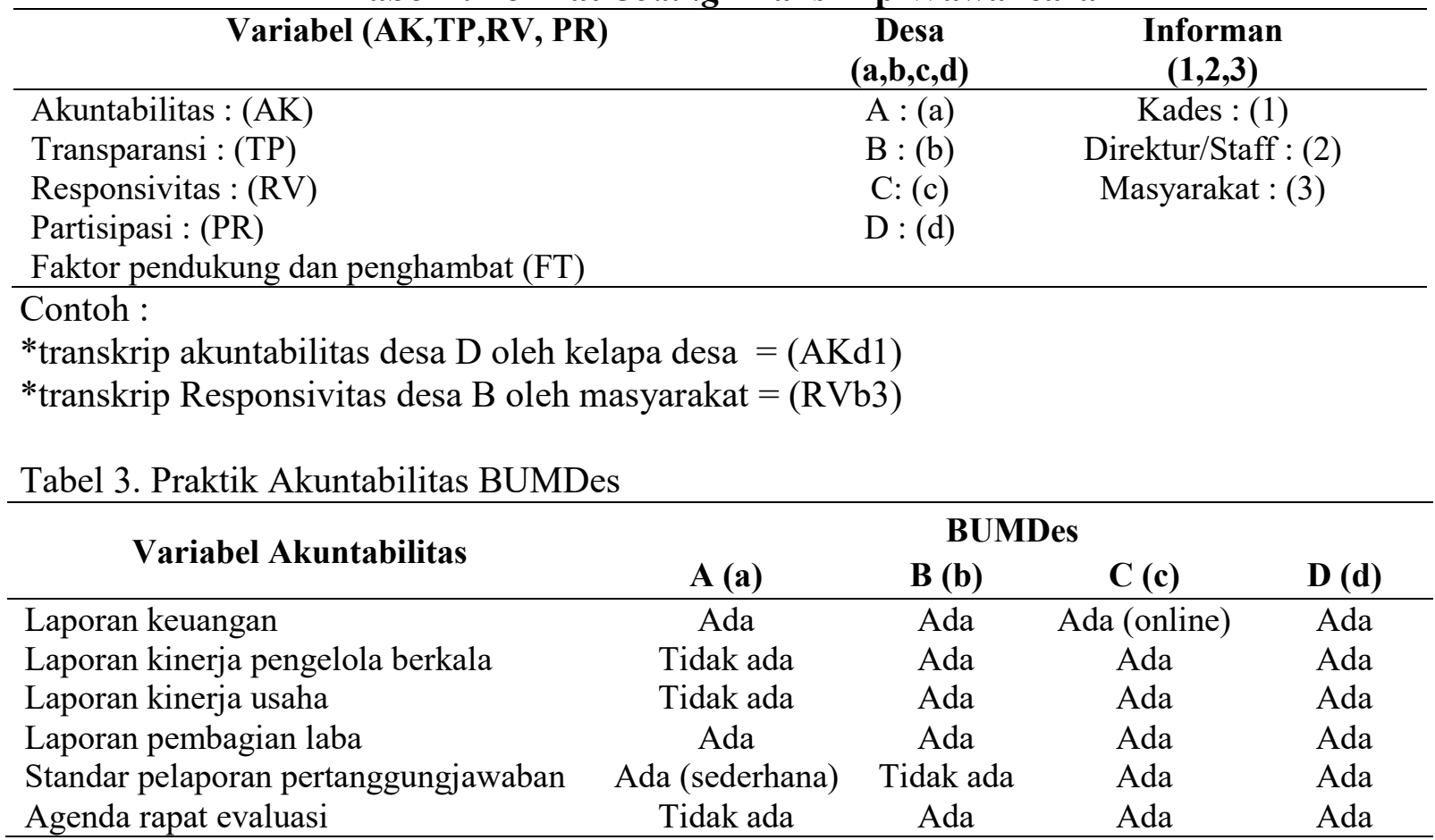


Dalam implementasi akuntabilitas yang dijalankan sebagai bentuk pertanggungjawaban pengelola BUMDes A kepada stakeholder dan masyarakat, pengelola telah membuat laporan keuangan, laporan rencana pembagian laba, serta laporan rencana usaha.

"Ada pelaporan hasil usaha yang dibuat, dan itu setiap tahun. Pada tahun 2018 kemarin keuntungan yang diperoleh sekitar Rp. 25.000.000..." (AKa2)

"sebenarnya untuk laporan targetnya itu sudah ada, tapi belum jalan, desa mart mati (tidak berjalan), jadi ya itu, yang berjalan hanya yang foto copy dan warung internet (warnet)" (AKa2)

Selanjutnya, laporan keuangan BUM-Des A telah dibuat dalam periode tahunan dan memiliki standar pelaporan pertanggungjawaban yang tertuang dalam AD/ART BUMDes. Artinya standar ini dibuat sendiri oleh pihak-pihak yang terlibat dalam pengurusan BUMDes. Hal ini sebagaimana informasi yang diperoleh dari Direktur BUMDes tersebut.

"sudah (standar laporan keuangan) ada, semacam $\mathrm{AD} / \mathrm{ART}$. Itu sudah dibuat karna (BUMDes) sudah berbadan hukum". (AKa1)

Walau demikian, laporan keuangan yang disajikan masih sederhana dan kurang lengkap karena hanya menyajikan laporan laba rugi serta laporan pembagian laba.

Menurut hasil wawancara, pada BUM-Des A ditemukan adanya pelaporan berkala terkait keuangan maupun kinerja yang tidak dilakukan, serta ditemukan pu-la tidak dilaksanakannya rapat evaluasi. Dari investigasi yang dilakukan peneliti ditemukan penyebab mengapa laporan berkala serta rapat evaluasi tidak dilakukan adalah karena dalam pengelolaan BUMDes telah terjadi dugaan penyelewengan dana dan sedang diproses oleh pihak kepolisian. Salah satu celah dan penyebab terjadinya praktik kecurangan dan penyelewengan dalam pengelolan BUMDes A ini adalah adanya tindakan ketidakpatuhan terhadap aturan yang telah ditetepakan. Hal tersebut ditunjukan dari dana modal usaha BUMDes yang turut dipegang oleh pendamping BUMDes yang seharusnya tidak diperbolehkan. Hal tersebut se-bagaimana pernyataan kepala desa :

"Saat ini dana modal BUMDes dibawa
sama mereka (pendamping BUMDes),
malah tidak jelas. Sebenarnya
pendamping itu tidak boleh pegang
(uang) BUMDes, tapi karna pengelola
sudah saling percaya ya kita sudah
percaya saja." (AKa1)

Dari data yang diperoleh di pemerintah provinsi DI. Yogyakarta, BUMDes A masuk dalam grade $\mathrm{A}$, artinya memiliki kinerja yang baik. Hal ini juga terkonfirmasi di lapangan yang ditunjukkan oleh kinerja BUMDes yang cukup progresif dimana unit-unit usahanya telah memperoleh keuntungan. Namun demikian, dari sisi tata kelola khususnya prinsip akuntabilitas, ternyata masih dinilai buruk. Temuan ini mengatkan ar-gumen bahwa praktik akuntabilitas me-mang berkaitan dengan adanya potensi tindakan kecurangan. Hal ini ditemukan pada BUMDes A dimana terdapat indi-kator akuntabilitas yang tidak dipenuhi, yakni agenda rapat evaluasi berkala antara pengelola BUMDes dan semua pemangku kepentingan. Ketika ini tidak dijalankan ternyata ditemukan adanya kasus kecurangan.

Di BUMDes B ditemukan bahwa laporan pertanggungjawaban pengelolaan BUMDes ini juga cukup baik dimana telah tersedia laporan keuangan, laporan kinerja berkala, laporan kinerja unit usaha, laporan pembagian laba, serta rapat evaluasi kinerja pengelolaan. BUMDes ini hampir 
memenuhi seluruh indikator akuntabilitas. Walau demikian, baik pengelola maupun pemerintah desa belum memiliki standar atau pun format baku dalam bentuk laporan pertanggug jawaban khususnya dalam laporan keuangan. Hal tersebut sebagaimana diungkapkan oleh bapak TA selaku kepala desa:

"belum ada (standar laporan), jadi kita hanya melihat hasil akhir. Jadi ada sisa cash berapa, asset nya apa, kemudian bentuk kegiatannya apa saja yang dilakukan bulan per bulannya. Jadi belum ada di AD/ART." (AKb1)

Belum adanya standar laporan pertanggungjawaban BUMDes dikarenakan BUMDes baru berjalan tiga bulan. Disamping itu, memang belum ada regulasi yang mengatur tantang laporan pertanggungjawaban BUMDes yang mewajibkan BUMDes menyajikan laporan tertentu berdasarkan suatu standar.

Sedangkan di BUMDes C laporan keuangan yang dibuat telah disajikan dalam dua bentuk yaitu laporan keuangan tahunan dan laporan keuangan berbasis online. Laporan keuangan tahunan yang disajikan terdiri dari laporan arus kas, laporan modal, laporan kas harian, neraca hingga laporan aset dan inventarisasi. Dalam membuat laporan keuangan yang disajikan secara online, pemerintah Desa $\mathrm{C}$ khususnya BUMDes bekerjasama dengan konsultan keuangan. Hal ini sebagimana yang disampaikan bendahara BUMDes:

"yah untuk mekanisme pertanggung jawabannya ya, kita kebetulan sudah pa-kai pelaporan secara online. Jadi kita bisa dipantau setiap hari baik itu pemasukan atau pengeluarannya. Kebetulan BUMDes kita bekerjasama dengan konsultan." (AKc2)

Dalam laporan pertanggungjawan BUMDes, juga disertakan laporan pembagian laba. Proporsi serta persentase pembagian laba dan penyertaan modal diasesuai dengan peraturan AD/ART BUMDes yang ditetapkan berdasarkan musyawarah komisaris dan pengelola BUMDes.

Hal tersebut sebagaimana dijelaskan oleh bapak S :

"Iya kita sampaikan (laporan pembagian laba), sesuai dengan peraturan $\mathrm{AD} / \mathrm{ART}$ untuk pembagian laba dan gaji. Jadi un-tuk penanaman modal usaha itu aada $25 \%$, keuntungan masuk ke Pendapatan Asli Desa (PAD) itu 25\%, keuntungan untuk penanam modal itu 40\%, dan ban-tuan social atau CSR it 5\%, bonus dengan pengurus BUMDes itu 5\%." (AKc2)

Selanjutnya, di BUMDes D, selain adanya laporan keuanga, juga ditemukan pelaporan kinerja BUMDes yang memuat laporan perkembangan usaha, aktifitas usaha, kendala usaha, dan stretegi binis yang dijalankan. Hal tersebut sebagaimana yang diungkapkan oleh bapak $\mathrm{K}$ selaku KADES dan penasehat BUMDes D:

"laporan kinerja juga ada di laporkan
dalam setiap laporan, mencakup
perkembanganganya bagaimana,
kerjanya bagaimana, kesulitanya
bagaimana, penyelesaiannya
bagaimana. Termasuk juga laporan
perencanaan kerja." (AKd1)

Walaupun laporan kinerja telah dibuat namun laporan tersebut hanya dilakukan dalam satu tahun sekali yaitu saat rapat tahunan, seingga belum dilaksanakan secara berkala. Sedangkan rapat kerja tahunan membahas rencana program serta teknis pelaksanaannya, rencana modal usaha, serta rapat evaluasi kinerja pengelola. Dalam rapat tahunan tersebut juga diseratakan laporan keuangan tahun sebelumnya untuk dijadikan bahan pertimbangan dalam pengambilan kebijakan. 
"Laporan keuangan tahun sebelumnya kita gunakan sebagai bahan pertimbangan pengambilan keputuasan. Setiap awal tahun begini kita adakan rapat kerja dan nanti di raker ini kita tentukan tahun ini kita mau buat program apa sih, selanjutnya seperti apa mekanismenya, dan dari mana modalnya, dan juga membicarakan evaluasi juga. Masalah keuanganpun juga dibicarakan,

\section{Implementasi Transparansi BUMDes}

Dalam mengukur Transparansi BUMDes indikator yang digunakan merujuk pada penelitian Y. P. Sari and Kismartini (2016) yang meliputi ketersediaan payung hukum akses publik, mekanisme informasi publikasi, ketersediaan sarana dan prasarana informasi publikasi serta ketersediaan informasi untuk publikasi. Hasil identifikasi indikator-indikator implementasi BUMDes disajikan pada Tabel 4.

Tabel 4. Praktik Transparansi BUMDes

\begin{tabular}{|c|c|c|c|c|}
\hline \multirow{2}{*}{$\begin{array}{c}\text { Variabel Transparansi } \\
\text { (TP) }\end{array}$} & \multicolumn{4}{|c|}{ BUMDes } \\
\hline & $\begin{array}{l}\text { A } \\
\text { (a) }\end{array}$ & $\begin{array}{l}\text { B } \\
\text { (b) }\end{array}$ & $\begin{array}{c}\mathrm{C} \\
\text { (c) }\end{array}$ & $\begin{array}{l}\text { D } \\
\text { (d) }\end{array}$ \\
\hline $\begin{array}{l}\text { Ketersedian payung } \\
\text { hukum akses publik }\end{array}$ & Tidak ada & Ada & Ada & Ada \\
\hline $\begin{array}{l}\text { Mekanisme informasi } \\
\text { publikasi }\end{array}$ & $\begin{array}{c}\text { Ada } \\
\text { (launcing } \\
\text { BUMDes dan } \\
\text { rapat) }\end{array}$ & $\begin{array}{c}\text { Ada } \\
\text { (sosmed dan } \\
\text { sosialisasi) }\end{array}$ & $\begin{array}{l}\text { Ada } \\
\text { (laporan } \\
\text { keuangan } \\
\text { berbasis } \\
\text { online) }\end{array}$ & $\begin{array}{c}\text { Ada } \\
\text { (social media) }\end{array}$ \\
\hline $\begin{array}{l}\text { Ketersediaan sarana } \\
\text { prasarana informasi } \\
\text { publikasi }\end{array}$ & Tidak ada & Ada & Ada & Ada \\
\hline $\begin{array}{l}\text { Ketersediaan informasi } \\
\text { untuk publikasi }\end{array}$ & $\begin{array}{c}\text { Ada } \\
\text { (Program dan } \\
\text { kebijakan } \\
\text { BUMDes) }\end{array}$ & $\begin{array}{c}\text { Ada } \\
\text { (Program dan } \\
\text { kebijakan } \\
\text { BUMDes) }\end{array}$ & $\begin{array}{c}\text { Ada } \\
\text { (Laporan } \\
\text { keuangan, } \\
\text { Program dan } \\
\text { kebijakan } \\
\text { BUMDes) }\end{array}$ & $\begin{array}{c}\text { Ada } \\
\text { (Program dan } \\
\text { kebijakan } \\
\text { BUMDes) }\end{array}$ \\
\hline $\begin{array}{l}\text { Kecepatan dan } \\
\text { kemudahan akses } \\
\text { informasi }\end{array}$ & Tidak ada & Mudah diakses & Mudah diakses & Mudah diakses \\
\hline
\end{tabular}

Merujuk pada Tabel 4 secara umum transparansi yang dilakukan empat BUMDes yang diteliti cukup beragam, mulai dari bentuk pelayanan hingga media publikasi. Hal tersebut dikarenakan publikasi yang dilakukan BUMDes didasarkan inisiatif pengelola BUMDes mengingat tidak adanya regulasi yang mengatur secara khusus tentang transparansi yang harus dilakukan dalam tata kelola BUMDes.

Keterbukan infromasi serta penentuan kebijakan pengelolan BUMDes dilakukan dengan mengadakan musyawarah bersama dengan seluruh elemen masyarakat sebagimana penyatan Bapak $G$ selaku pengelola BUMDes A :

"Oh iya. Kita ada sosialisasi tentang kebijakan-kebijakan dan rencana kita. Kita undang semua perwakilan RT, dan kita sosialisasikan. Kita beritahukan kalau kita ada unit usaha foto copy, juga ada warnet." (TPa2) 
Berkaitan dengan bentuk publikasi hanya dilakukan dengan melakukan sosialisasi sederhana ke masyarakat, belum ada mekanisme khusus untuk publikasi baik itu kebijakan maupun laporan keuangan dalam bentuk media cetak, poster dan lain sebagainya.

Hal serupa juga dilakukan oleh pengelolaan BUMDes B dimana publikasi BUMDes dilakukan melalui sosialiasi kepada masyarakat. Sosialisasi dilakukan sebagai upaya pengenalan BUMDes kepada masyarakat, pemerintah menjelaskan peran dan manfaaat BUMDes bagi masyarakat. Pemerintah mengharapkan dengan meningkatnya pemahaman masyarakat terhadap peran BUMDes sehingga membangun rasa kepemilikan dan kepentingan bersama membangun BUMDes. Hal tersebut sebagaiamana diungkapkan sekertaris BUMDes B :

\begin{abstract}
"Kita juga berusaha sosialisasi kepada masyarakat mengenai peran BUMDes itu sendiri, soalnya banyak masyarakat yang belum tahu, Ngapain Bumdesbumdesan, kita berusaha menjelaskan kepada masyarakat bah-wa Bumdes ini merupakan usahanya desa, bisa dikatakan ini perusahaanya milik desa, sehingga semua manfaat akan kembali ke desa itu juga, jadi masyarakat sadar dan merasa memiliki kepentingan yg sama dengam bumdes, sehingga masyarakat juga mendukung unit usaha bumdes dan berjalan bersama-sama" $(\mathrm{TPb} 2)$
\end{abstract}

Sosialiasi BUMDes begitu penting dilakukan oleh pengelola mengingat BUMDes A dan B merupakan BUMDes yang masih baru resmi berdiri. Pengelola juga melakukan publikasi kebijakan BUMDes melalui media sosial seperti instagram. Media sosial digunakan sebagai sarana promosi marketing serta publikasi program dan kebijakan BUMDes.
Sedangkan keterbukaan informasi pengelolaan BUMDes $\mathrm{C}$ diwujudkan dalam bentuk laporan keuangan yang berbasis online, sehingga seluruh kegiatan pengelola seperti anggaran dapat dilihat dan diakses masyarakat dengan mudah dan memperoleh laporan yang aktual.

"yah untuk mekanisme pertanggung jawabannya ya, kita kebetulan sudah pakai pelaporan secara online. Jadi kita bisa dipantau setiap hari baik itu pemasukan atau pengeluarannya. Kebetulan BUMDes kita bekerjasama dengan salah satu konsultan akuntansi." (TPc2)

Selanjutnya, di BUMDes desa C, transparansi tekait kebijakan pengelolaan juga diwujudkan dalam agenda rapat bulanan bersama dengan pemerintah desa dan perwakilan masyarakat yang membahan evaluasi kinerja dan pengelolaan BUMDes. Hal tersebut sebagaimana diungkapkan seketaris oleh staff BUMDes C :

"Untuk kinerja kita itu selalu ada evaluasi setiap bulannya. Jadi kita itu ada rapat rutin dengan pemerintah desa dan perwakilan masyarakat. Nanti pada pertemuan ini kita bahas bagaimana kinerja dari BUMDes, pengelolanya, dan lain-lainnya." (TPc2)

Sementara di BUMDes D, upaya publikasi terkait kebijakan pengelola dilakukan melalui musyawarah kerja rutin yang terdiri dari pengelola internal BUMDes, Pengawan BUMDes yang berasal dari BPD (badan permusyawaratan desa) serta Karang Taruna. Sedangkan publikasi melalui surat kabar, media elektronik dan sosial media seperti Instagram dan Facebook lebih kepada strategi pemasaran untuk pengembangan unit usaha. Hal tersebut sebagaimana diungkapkan oleh seketaris BUMDes : 
“... Informasi (terkait BUMDes) untuk masyarakat ini kita sebarkan melalui media sosial kita seperti insatgram, facebook, dan website. Kita juga bikin baliho dan banner banner yang ditempel di pinggir-pinggir jalan sama yang paling sering di buat ya ini pamflet ini." (TPd2)

\section{Implementasi Responsivitas BUMDes}

Dalam mengukur Responsivitas Transparansi BUMDes indikator yang digunakan merujuk pada penelitian Pratama and Pambudi (2017) yang meliputi Jenis usaha BUMDes dan Respon pengelola. Hasil identifikasi indikatorindikator implementasi BUMDes disajikan pada Tabel 5.

Berdasarkan Tabel 5 secara umum empat BUMDes yang diteliti telah menjalankan unit usahanya dengan menyesuaikan apa yang menjadi kebutuhan masyarakat serta memanfaatkan potensi daerahnya dengan baik. Selain itu respon pengelola sebagai bentuk pelayanan kepada masyarakat juga telah dijalankan dengan baik.

BUMDes A pada awalnya berdiri dengan empat unit usaha, unit usaha fotocopy, unit usaha warung internet atau warnet, unit usaha toko sembako Desamart, dan unit usaha pengelolaan sampah. Unit-unit usaha BUMDes terse-but berdiri sebagai upaya untuk memanfaatkan peluang bisnis dan memenuhi kebutuhan masyarakat.

Usul dan saran serta masukan yang disampaikan oleh masyarakat diterima melalui rapat bersama pengelola BUMDes dengan seluruh elemen masyarakat desa, hal tersebut sebagaimana diungkapakan oleh bapak G selaku pengelola BUMDes :

"Oh iya ada banyak (pembentukan unit usaha BUMDes hasil dari usulan/aspirasi masyarkaat). Banyak aspirasi masyarakat yang kemudian kita tindaklanjuti sebagai unit usaha BUMDes jika memungkinkan.“" (Rva2)
Dalam pengelolaan BUMDes B, pengelola membuat mekanisme penerimaan aspirasi, saran dan masukan dari masyarakat melalui rapat ruting yang dilakukan bersama dengan pemerintah desa. Pengelola BUMDes juga memberikan respon atas saran, masukan serta keluhan yang disampaikan dalam salah satu unit usaha BUMDes tersebut. Dimana para pedagang mengelukan sepinya pasar kemudian pengelola dengan tanggap memberikan respon dengan merancang program yang lebih tepat sasaran untuk upaya meramaikan pasar, hal tersebut sebagaimana diungkapkan oleh bapak L selaku pengelola BUMDes :

"untuk sejauh ini aspirasi kita respon dengan segera, beberapa keluhan dari masyarakat khususnya para penjual di pasar yang mengelukan sepinya pasar (sa-lah satu unit usaha BUMDes B). Nah dari pengelola memberika respon dengan merencanakan program yg lebih menyasar ke anggota masyarakat. Untutk terkait pengadaan barang bangunan juga ketika ada saran dan masukan dari masyarakat maka kita respon dengan baik..." (RVb2)

Sedangkan BUMDes C memiliki berbagai unit usaha meliputi Pengelolaan pasar desa, Pengelolaan sampah terpadu 3R, Laborat tani modern hortikultura, Pengelolaan air bersih (PAMSIMAS), dan Etalase hasil produksi UKM. Pendirian unit usaha didasarkan pada kebutuhan warga masyarakat sekitar, hal tersebut dapat dilihat dari unit usaha air bersih (PAMSIMAS) sebagai bentuk pemenuhan kebutuhan warga desa $\mathrm{C}$ yang secara geografis sulit mendapatakan lain. Pemerintah juga memperhatikan kebutuhan masyarakat dari segi ekonomi sehingga mendirikan unit usaha etalase produk UKM dan pasar desa. Hal tersebut sebagaimana yang diungkapkan pengelola BUMDes : 
"saat ini kita ada unit usaha BUMDes pengolahan TPST3R, lalu pengolahan sumber daya alam, pengelolaan air, perdagangan, sarana dan hasil pertanian yang meliputi perkebunan, peternakan, perikanan, agrobisnis, dan multikultura, lalu ada juga usaha mikro kecil menengah, kegiatan ekonomi yang dibutuhkan oleh warga, lalu UMKM. Lebih ke pem-binaan ke UMKM." (RVc2)

Tabel 5. Praktik Responsivitas BUMDes

\begin{tabular}{|c|c|c|c|c|}
\hline Variabel & \multicolumn{4}{|c|}{ BUMDes } \\
\hline $\begin{array}{l}\text { Responsivitas } \\
\text { (RV) }\end{array}$ & $\begin{array}{l}\text { A } \\
\text { (a) }\end{array}$ & $\begin{array}{l}\text { B } \\
\text { (b) }\end{array}$ & $\begin{array}{l}\mathrm{C} \\
\text { (c) }\end{array}$ & $\begin{array}{l}\text { D } \\
\text { (d) }\end{array}$ \\
\hline Jenis usaha BUMDes & $\begin{array}{l}\text { - Foto copy } \\
\text { - Warnet } \\
\text { - Toko } \\
\text { sembako } \\
\text { - Pengelolaan } \\
\text { sampah }\end{array}$ & $\begin{array}{l}\text { - } \text { Pasar } \\
\text { unggas } \\
\text { - Toko } \\
\text { material }\end{array}$ & 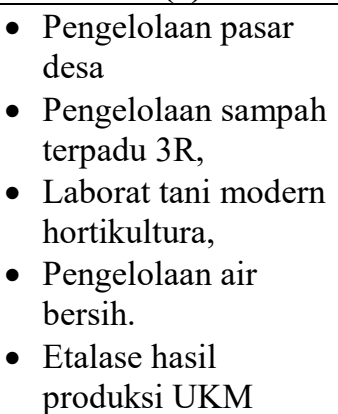 & $\begin{array}{l}\text { - Wisata puri } \\
\text { mataram } \\
\text { - Budidaya } \\
\text { hortikultural }\end{array}$ \\
\hline $\begin{array}{l}\text { Respon Pengelola } \\
\text { dalam pelayanan }\end{array}$ & $\begin{array}{l}\text { Segala bentuk } \\
\text { saran dan } \\
\text { masukan dari } \\
\text { masyarakat } \\
\text { direpon dengan } \\
\text { baik oleh } \\
\text { pengelola }\end{array}$ & $\begin{array}{l}\text { Segala bentuk } \\
\text { saran dan } \\
\text { masukan dari } \\
\text { masyarakat } \\
\text { direspon } \\
\text { dengan baik } \\
\text { oleh pengelola }\end{array}$ & $\begin{array}{l}\text { Segala bentuk saran } \\
\text { dan masukan dari } \\
\text { masyarakat direspon } \\
\text { dengan baik oleh } \\
\text { pengelola }\end{array}$ & $\begin{array}{l}\text { Segala bentuk saran } \\
\text { dan masukan dari } \\
\text { masyarakat } \\
\text { direspon dengan } \\
\text { baik oleh pengelola }\end{array}$ \\
\hline $\begin{array}{l}\text { Kecepatan respon } \\
\text { pengelolaan }\end{array}$ & $\begin{array}{l}\text { Saran dan } \\
\text { masukan } \\
\text { direspon hanya } \\
\text { dalam rapat } \\
\text { tahunan. }\end{array}$ & $\begin{array}{l}\text { Saran dan } \\
\text { masukan } \\
\text { direspon } \\
\text { dengan } \\
\text { langsung } \\
\text { dalam } \\
\text { mekanisme } \\
\text { rapat rutin }\end{array}$ & $\begin{array}{l}\text { Saran dan masukan } \\
\text { direspon dengan } \\
\text { langsung dalam } \\
\text { mekanisme MUSDES } \\
\text { dan sosialisasi mitra } \\
\text { UMKM }\end{array}$ & $\begin{array}{l}\text { Saran dan masukan } \\
\text { ditanggapi atau } \\
\text { direspon langsung } \\
\text { melalui media } \\
\text { sosial BUMDes }\end{array}$ \\
\hline $\begin{array}{l}\text { Program pelayanan } \\
\text { telah sesuai } \\
\text { kebutuhan }\end{array}$ & $\begin{array}{l}\text { Sesuai } \\
\text { kebutuhan } \\
\text { masyarakat }\end{array}$ & $\begin{array}{l}\text { Sesuai } \\
\text { kebutuhan } \\
\text { masyarakat }\end{array}$ & $\begin{array}{l}\text { Program pelayanan } \\
\text { sesuai kebutuhan } \\
\text { masyarakat }\end{array}$ & $\begin{array}{l}\text { Program pelayanan } \\
\text { sesuai dengan } \\
\text { potensi desa }\end{array}$ \\
\hline
\end{tabular}

\section{Implementasi Partisipasi Masyarakat}

Dalam mengukur partisipasi masyarakat dalam pengelolaan BUMDes indikator yang digunakan merujuk pada penelitian Mustanir (2017) yang meliputi bentuk keterlibatan masyarakat, masyarakat ukut andil dalam pengambilan keputusan, dan Penerimaan manfaat keberadaan BUMDes. Hasil identifikasi indikatorindikator implementasi BUMDes disajikan pada Tabel 6.

Secara umum empat BUMDes yang diteliti telah banyak melibatkan masyarakat baik dalam pengelolan maupun pengambilan keputusan dan kebijakan BUMDes.
Masyarakat dilibatkan dalam hal pengelolaan dimana direkrut sebagai pengelola unit-unit usaha BUMDes hingga penerima manfaat baik secara langsung maupun tidak langsung dari unit usaha yang dijalankan.

Di BUMDes A, dalam praktik partisipasi, mekanisme pengambilan keputusan dilakukan secara terbuka kepada masyarakat dimana dalam penentuan kebijakan dilakukan bersama dengan badan permusyawarat desa serta perwakilan masyarakat. Sebagaimana dinyatakan oleh bapak $\mathrm{S}$ selaku kepala desa: 
"Dalam pengambilan keputusan dan kebijakan dari awal pendirian BUMDes ya di rapat-rapat kita undang perwakilan masyarata di BPD dalam perancanaaan waktu itu." (PRa1)

Tabel 6. Praktik Partisipasi Masyarakat terkait BUMDes

\begin{tabular}{|c|c|c|c|c|}
\hline Variabel & \multicolumn{4}{|c|}{ BUMDes } \\
\hline $\begin{array}{l}\text { Partisipasi } \\
\text { (PR) }\end{array}$ & $\begin{array}{c}\text { A } \\
\text { (a) }\end{array}$ & $\begin{array}{c}\text { B } \\
\text { (b) }\end{array}$ & $\begin{array}{l}\mathrm{C} \\
\text { (c) }\end{array}$ & $\begin{array}{l}\text { D } \\
\text { (d) }\end{array}$ \\
\hline $\begin{array}{l}\text { Bentuk } \\
\text { keterlibatan } \\
\text { masyarakat }\end{array}$ & $\begin{array}{ll}\text { - } & \text { Staff } \\
\text { pengelola } \\
\text { BUMDes } \\
\text { - } \text { Karyawan } \\
\text { unit usah }\end{array}$ & $\begin{array}{l}\text { - Staff pengelola } \\
\text { BUMDes } \\
\text { - Karyawan unit } \\
\text { usah } \\
\text { - Pedagang pasar } \\
\text { unggas }\end{array}$ & $\begin{array}{l}\text { - Staff pengelola } \\
\text { BUMDes } \\
\text { - Karyawan unit } \\
\text { usah } \\
\text { - Pedagang pasar }\end{array}$ & $\begin{array}{l}\text { - Staff pengelola } \\
\text { BUMDes } \\
\text { - Karyawan unit usah } \\
\text { - Pedagang pasar }\end{array}$ \\
\hline $\begin{array}{l}\text { Masyarakat ikut } \\
\text { andil dalam } \\
\text { pengambilan } \\
\text { keputusan }\end{array}$ & $\begin{array}{l}\text { Dalam } \\
\text { musyawaran } \\
\text { pendirian } \\
\text { BUMDes }\end{array}$ & $\begin{array}{l}\text { Dalam agenda } \\
\text { annual meeting } \\
\text { tahunan }\end{array}$ & $\begin{array}{l}\text { Dalam musyawarah } \\
\text { desa yang diwakili } \\
\text { BPD dan } \\
\text { karangtaruna }\end{array}$ & $\begin{array}{l}\text { Dalam musyawaran } \\
\text { pendirian BUMDes }\end{array}$ \\
\hline $\begin{array}{l}\text { Penerimaan } \\
\text { manfaat } \\
\text { keberadaan } \\
\text { BUMDes }\end{array}$ & $\begin{array}{l}\text { Penyedia jasa } \\
\text { kebutuhan } \\
\text { masyarakat } \\
\text { melalui unit } \\
\text { usaha fotocopy }\end{array}$ & $\begin{array}{l}\text { Manfaat secara } \\
\text { langsung dan tidak } \\
\text { langsung }\end{array}$ & $\begin{array}{l}\text { Unit usaha BUMDes } \\
\text { memberikan manfaat } \\
\text { baik secara ekonomi } \\
\text { maupun kebutuhan } \\
\text { dasar seperti air } \\
\text { bersih dan } \\
\text { pengelolaan sampah }\end{array}$ & $\begin{array}{l}\text { Masyarakat } \\
\text { mendapatan manfaat } \\
\text { secara ekonomi } \\
\text { dengan adanya tempat } \\
\text { wisata, pasar, dan } \\
\text { pengelolaan lahan } \\
\text { parkir oleh karang } \\
\text { taruna }\end{array}$ \\
\hline
\end{tabular}

Dalam pengambilan keputusan dan kebijakan pengelola BUMDes B diadakan rapat umum tahunan atau disebut annual meeting. Rapat tersebut membahas rencana program kerja satu tahun kedepan serta teknis pelaksanaan kegiatan. Rapat tahunan turut serta melibatkan seluruh masyarakat mulai dari masyarakat desa, rekan desa, Lembaga Kemasayarakatan Desa (LKD), Lembaga Pemberdayaan masayarkaat Desa (LPMD), komunitas, karangtaruna hingga tokoh masyarakat berpastisipasi dalam pengambilan keputusan, sebagaimana diungkapkan pengelola BUMDes B yaitu bapak L :

"Untuk annual meeting kita lakukan satu tahun sekali. Di situ BUMDes melibatkan semua elemen yang ada di desa, mulai dari masyarakt desa, rekan desa, LKD, LPMD, komunitas dan juga para tokoh masyarakat." (PRb2)

Kemudian bentuk partisipasi masyarakat dalam pengelolaan BUMDes D diwujudkan dengan turut terlibatnya warga masyarakat desa dalam proses penentuan arah dan strategi serta kebijakan dalam pengelolaam melalui musywarah. Dalam menjalankan unit usaha BUMDes D sebagian besar karyawan berasal dari masyarkat desa sekitar, dengan persentase $80 \%$ warga sekitar dan $20 \%$ diambil dari luar karena membutuhkan pegawai profesional yang memiliki keahlian dibidang tertentu hal itu ditentukan berdasarkan inisiatif dan kesepakatan bersama warga desa. Sebagaimana diungkapkan oleh Sekertaris BUMDes D:

“... di BUMDes ini punya karyawan, $80 \%$ warga sekitar dan $20 \%$ kita ambil dari luar atau bisa dibilang pegawai professional yang punya kemampuan dalam bidang tertentu..." (PRd2)

Masyarakat di desa D dilibatkan hampir dalam semua aspek, mulai dari Staff BUMDes, karyawan di unit-unit usaha BUMDes, Tukang Bangunan, hingga 
penggeolaan parkir yang Pengelolaannya diserahkan sepenuhnya kepada Karangtaruna. Hal tersebut diungkapkan oleh pengelola BUMDes D yaitu Bapak J :

"Semuanya masyarkat. Makanya kan dari pengelola yang ada di puri mataram ini ada kita ngkat dari karang taruna dan ibu pkk nya, itu yang parkiran saja kita kasih hak penuh untuk masyarakat mengelola dengan catatan harus tetap melapor biar kita juga kan tau dan tambahan mas, tiap hari Minggu itu kita ada pasar, namanya Pasar Ndelik nanti itu pesertanya warga dari desa ini dengan menjual makanan khas, jajanan pasar gitu lah mas kayak putu, nagasari gitu.ini dikelola sama anak-anak karang taruna, paling yang jualan hanya dikenakan uang kebersihan Rp.5000. begitu (PRd2)

Keterlibatan masyarakat juga di-wujudkan dalam bentuk kebebasan ber-partisipasi sebagai pedagang di salah unit usaha BUMDes D, yakni lahan parkir, tempat wisata, dan pasar. Hal tersebut sebagaimana diungkapkan oleh Ibu L selaku warga masyarakat.

“... kami masyarakat tiap hari minggu ada kesempatan jualan di Pasar Ndelik (salah satu unit usaha BUMDes D). Dis-itu masyarakat bebas mau jualan apa sa-ja. Yang penting jaga kebersihan aja sih mas" (PRd3)

\section{PEMBAHASAN}

Dari penelitian yang dilakukan terhadap empat BUMDes yang berada di DIY dapat disimpulkan bahwa implementasi akuntabilitas dilihat dari beebrapa indikator yang ditentukan telah dijalankan dengan baik oleh BUMDes se-bagian besarnya. Hal tersebut ditunjukan dari telah adanya laporan keuangan, laporan kinerja pengelolaan, laporan rencana pembagian laba, serta adanya standar pelaporan pertanggungjawaban. Walau demikian, standar laporan keuangan belum mengacu pada suatu standar tertentu seperti Pernyataan Standar Akuntansi Keuangan (PSAK). Hal tersebut dikarenakan belum adanya regulasi yang mengatur tentang mekanisme laporan pertanggungjawaban maupun standar pelaporan. Karenanya, penting bagi regulator untuk menin-daklanjuti temuan ini, agar praktik pengelolaan dan pelaporan keuangan BUMDes menjadi terstandar dan seragam.

Meskipun menghadapi ketiadaan standar, empat BUMDes yang diteliti te-lah mampu menyusun laporan keuangan meskipun dalam bentuk yang relatif sederhana. Kurangnya kompetensi sumber daya manusia (SDM) dalam pengelolaan BUMDes menyebabkan laporan yang disajikan berbentuk sederhana tersebut. Temuan ini serupa dengan penelitian yang dilakukan Dalam penelitian Mahmudah (2019) bahwa akuntabilitas laporan keuangan BUMDes masih sederhana yakni berupa catatan pengeluaran dan pemasukan, dan tidak ada laporan keuangan yang lengkap seperti neraca, perubahan ekuitas, dan catatan atas laporan keuangan. Hal ini tidak lepas dari ketiadaan standar dan kurangnya kompetensi SDM.

Semetara itu jika melihat esensi dan tujuan dari pelaporan, orientasi akuntabil-itas adalah untuk pengambilan keputusan yang tepat. Ketika laporan yang disajikan terlalu sederhana maka dikhwatirkan tidak akan menggambarkan kondisis bisnis BUMDes secara utuh sehingga informasi yang disajikan tidak cukup untuk mengabil keputusan secara tepat dan strategis. Putra and Mulyani (2019) menemukan bahwa informasi laporan keuangan akan berpengaruh terhadap kualitas pengambilan keputusan pemerintah. Hal tersebut mengindikasikan bahwa kualitas laporan keuangan mem-iliki peran penting bagi suatu entitas un-tuk dapat 
memberikan gambaran mengenai kondisi keuangan entitas secara utuh, termasuk BUMDes, sehingga mana-jemen dapat menentukan kebijakan ke de-pan secara tepat, khususnya terkait pengembangan BUMDes. Oleh karenanya, agar BUMDes memenuhi aspek akuntabil-itas ini maka perlu adanya standar pelaporan, SDM yang kompeten, dit-ambah dengan dukungan teknologi yang memadai. Selain itu, juga diperlukan pendampingan untuk menyesuaikan laporan keuangan yang berterima umum, serta perlunya pelatihan untuk para staff BUMDes tentang pengolaan BUMDes secara profesional.

Dari salah satu BUMDes yang diteli-ti, juga ditemukan penyebab indikatorindikator akuntabilitas tidak berjalan secara optimal dimana pengelola tidak melakukan laporan berkala terkait keuangan maupun laporan kinerja pengelolaan serta tidak dilaksanakannya rapat evaluasi. Dari investigasi yang dilakukan, ditemukan penyebab mengapa pelaporan berkala serta rapat evaluasi tidak dilakukan adalah karena dalam pengelolaan BUMDes telah terjadi dugaan penyelewengan dana modal dan sedang dalam proses penyelidikan pihak yang berwajib. Salah satu celah dan penyebab terjadinya praktik kecurangan dan penyelewengan dalam pengelolan BUMDes ini diduga karena adanya tindakan ketidakpatuhan terhadap aturan yang telah ditetepakan, yakni AD/ART. Hal tersebut ditunjukan dari dana modal usaha BUMDes yang turut dipegang oleh pendamping BUMDes yang seharusnya tidak diperbolehkan. Temuan ini mengindikasikan bahwa prinsip tata kelola yang baik lainnya yang harus dijalankan BUMDes untuk memitigasi kecurangan adalah supremasi hukum. Karenanya, perlu adanya dewan atau unit yang mengawasi pelaksanaan aturan di BUMDes yang sifatnya mungkin mirip dengan auditor internal (Nguyen \& Van Dijk, 2012; Pillay, 2004).
Dari sisi responsivitas, BUMDes perlu mempertimbangkan kebutuhan, as-pirasi, dan kebermanfaatan produk jualan terhadap masyarakat dengan melihat potensi-potensi daerah yang ada. Dalam hal ini hanya BUMDes $\mathrm{C}$ yang memiliki unit usaha yang betul-betul sesuai dengan kebutuhan masyarakat. Hal itu ditunjukan dari unit usaha pengelolaan air bersih yang sangat dibutuhkan oleh masyarkatnya. Ide dari produk jualan ini tidak lepas dari responsivitas yang baik dari BUMDes. Oleh karen misi BUMDes tidak hanya aspek ekonomi tetapi juga so-cial, maka selain focus kepada pening-katan ekonomi dan pendapatan desa serta masyarakat desa, penting bagi BUMDes untuk juga berfokus kepada pengentasan masalah lingkungan sosial seperti air kon-sumsi, sampah, saluran air, biogas, dan lain sebagainya (Gibbon \& Affleck, 2008).

Selanjutnya, implementasi prinsip partisipasi di BUMDes telah berjalan baik dimana porsi terbesar masyarakat dalam pengelolaan dan pelaksanan BUMDes berasal dari Karang Taruna. Partisipasi ini berkontibusi terhadap perkembangan BUMDes khususnya dari segi kelembagaan, pengelolaan dan pemasaran produk. Hasil ini sejalan dengan penelitian Kasila and Kolopaking (2018) tentang partisipasi pemuda desa dalam perkembangan usaha BUMDes. Mereka menemukan bahwa tingkat partisipasi masyarakat yang tinggi berasal dari pemuda desa yang telah mampu memberikan kemajuan terhadap perkembangan BUMDes.

Selain itu, mengacu pada konsep social enterprice, BUMDes berdiri sebagai bentuk perusahaan sosial dimana lebih berfokus untuk memberikan manfaat sosial kepada masyarakat (Gibbon \& Affleck, 2008). Badan usaha berdiri tidak hanya berorientasi pada finasial perusahaan secara khusus, melainkan untuk membangun kemandirian desa dan membangun perekonomian masyarakat dengan memanfaatkan potensi daerah 
secara maksimal. Sebagimana BUMDes C dalam unit usaha Etalase UMKM yang didirikan sebagai fungsi sosial, unit usaha dagang ini didirikan tidak untuk bersaing dengan warung atau toko milik warga melainkan menghimpun produk-produk masyarakat sekitar yang kemudian dipasarkan secara lebih luas secara terkonsep. Temuan ini juga bagian dari bentuk responsivitas BUMDes yang setiap kegiatan yang dilaksanakan harus sejalan dengan kebutuhan masyarakat.

Disisi lain, ada temuan menarik bahwa adanya data cluster atau Grade BUMDes milik pemrpov DIY ternyata kontradiktif dengan temuan di lapangan dimana BUMDes dengan grade Tinggi (A) justru memiliki tata kelola yang relatif kurang memuaskan diukur dengan indikatorindikator yang digunakan pada studi ini. Hal tersebut menimbulkan pertanyaan mengenai indikator apa yang digunakan oleh Pemprov DIY dalam menilai BUMDes. Isu ini dapat menjadi peluang untuk dilakukannya penelitian mengenai konstruksi indikator progres perkembangan BUMDes yang lebih robust.

Dari sudut pandang teoritis, hasil-hasil penelitian ini secara eksplisit kami kupas menggunakan teori institusional, khususnya mekanisme isomorphism (DiMaggio \& Powell, 1983). Pada kasus empat BUMDes di DIY yang menjadi subyek penelitian ini, implementasi praktik akuntabilitas, transparansi, responsivitas serta partisipasi masyarakat dalam pengelolaan BUMDes lebih di-dorong oleh kesadaran para pengelola BUMDes. Tidak adanya tekanan regulasi seperti aturan-aturan yang mengatur secara eksplisit tentang pengelolaan BUMDes memicu untuk melakukan pengelolan dan praktik tata kelola BUMDes secara mandiri berdasarkan kesadaran dan inisiatif.

Secara teknis pelembagaan tata kelola yang baik lebih dikarenakan tekanan normative dimana untuk memenuhi aspek ta- ta kelola tersebut, pihak BUMDes merekrut orang dari luar desa yang memiliki kompetensi bisnis dan melibatkan konsultan akuntansi. Pratik-praktik yang dijalankan tersebut juga dilakukan bukan berdasar upaya eniru lembaga BUMDes lain yang dianggap lebih maju, karena faktanya dalam implementasi praktik dilakukan secara berbeda-beda dari setiap BUMDesnya. Oleh karenanya, terlepas dari masih belum optimalnya implementasi prinsip-prinsip tata kelola yang baik oleh empat BUMDes ini, apa yang mereka lakukan telah menunjukkan adanya komitmen yang kuat dari para pengelola untuk mengelola BUMDes secara baik.

\section{KESIMPULAN DAN SARAN Kesimpulan}

Berdasarkan hasil penelitian terhadap empat BUMDes di Yogyakarta yang diteliti dengan teknik wawancara kepada beberapa Kepala desa, Direktur BUMDes, Staf BUMDes, dan masyarakat, dapat diambil kesimpulan bahwa tata kelola BUMDes ditinjau dari prinsip akuntabilitas, transparansi, responsivitas, dan partisipasi masyarakat sudah berjalan cukup baik. Hal ini ditunjukkan terpenuhinya secara mayoritas indikatorindikator prinsip tata kelola yang baik. Dari aspek akuntabilitas dan transparansi BUMDes, telah dilakukan dengan baik dengan membuat laporan keuangan tahunan yang dipublikasi, laporkan kinerja pengelola berkala, dan recana usaha serta adanya mekanisme publikasi yang telah mengunakan media sosial sehingga meningkatkan aksesibilitas publik. Dari sisi responsivitas, BUMDes telah mempertimbangkan kebutuhan dan kebermanfaatan terhadap masyarakat serta melihat potensi-potensi daerah yang ada. serta BUMDes telah memberika pelayanan yang baik terhadap masyarakat melalui mekanisme penerimaan aspirasi masyarakat. Dari segi partisipasi masyarakat, BUMdes telah melibatkan masyarakat untuk secara aktif mengelola 
BUMDes sebagai staf pengelola maupun mitra usaha BUMDes sehingga masyarakat juga menerima manfaat dari keberadaan BUMDes itu sendiri. Disamping itu sumber daya manusia dan modal menjadi faktor pendukung Tata kelola BUMDes.

Keterbatasan dalam penelitian ini adalah subjek penelitian yang sangat terbatas, yakni hanya melibatkan empat BUMDes dari dua Kabupaten di DIY, sehingga hasil penelitian belum dapat menggambarkan keadaan BUMDes secara luas di seluruh indonesia. Karenanya, penelitian berikutnya disarankan untuk mengunakan cakupan yang lebih luas ten-tunya dengan pendekatan lain, seperti sur-vey, agar hasil penelitian dapat mengeneralisir dalam suatu kawasan tertentu. Disamping itu, variabel penelitian yang digunakan hanya memberikan wawasan terkait implementasi empat prinsip tata kelola yang baik di BUMDes, dan juga penelitian ini tidak mengaitkan empat prinsip tersebut dengan kontribusi tertentu, misalnya kinerja BUMDes. Oleh karenanya, penelitian selanjutnya disarankan menggali prinsipprinsip lain dari tata kelola yang baik misalnya supremasi hukum, keadilan, dan orientasi kepada visi dan misi. Juga disarankan menguji prinsip-prinsip tata kelola yang baik di BUMDes secara empiris terhadap kinerja atau peran BUMDes terhadap kesejahteraan masyarakat di desa. Hal ini akan memberikan tambahan wawasan dalam isu perkembangan BUMDes di Indonesia.

\section{Saran}

Dari hasil penelitian ini, implikasi penting yang perlu diperhatikan adalah agar BUMDes dapat meningkatkan prak-tik tata kelola yang baik karena masih te-radpat beberapa BUMDes yang belum menjalankan beberapa indikator tata kelola yang baik tersebut. Hal ini penting agar BUMDes dapat dijalankan secara baik, khususnya akuntabel dan transparan guna memtigasi risiko korupsi se-bagaimana yang terjadi di BUMDes C. Selain itu, responsivitas dan partisipasi masyarakat penting dilaksanakan agar BUMDes berjalan sesuai dengan filosofi tujuannya, yakni menjadi lembaga bisnis yang berkontribusi secara ekonomi dan juga sosial sehingga mampu memajukan kemakmuran masyarakat di desa.

\section{REFERENSI}

Afiah, N. N., \& Rahmatika, D. N. (2014). Factors influencing the quality of financial reporting and its implications on good government governance. International Journal of Business, Economics and Law, 5(1), 111-121.

Agunggunanto, E. Y., Arianti, F., Kushartono, E. W., \& Darwanto, D. (2016). Pengembangan Desa Mandiri Melalui Pengelolaan Badan Usaha Milik Desa (BUMDes). Jurnal Dinamika Ekonomi \& Bisnis, 13(1).

Ahyaruddin, M., \& Akbar, R. (2018). Indonesian Local Government's Accountability and Performance: The Isomorphism Institutional Perspective. Journal of Accounting and Investment, 19(1), 1-11.

Anggraeni, M. R. R. S. (2017). Peranan Badan Usaha Milik Desa (BUMDes) Pada Kesejahteraan Masyarakat Pedesaan Studi Pada Bumdes Di Gunung Kidul, Yogyakarta.

Baxter, P., \& Jack, S. (2008). Qualitative case study methodology: Study design and implementation for novice researchers. The qualitative report, 13(4), 544-559.

Connolly, C., \& Kelly, M. (2011). Understanding accountability in social enterprise organisations: a framework. Social enterprise journal.

Cooper, D., \& Schindler, P. (2014). Business Research Methods. (C) The McGraw- Hill Companies. 
Creswell, J. W. (2012). Research Design: Qualitative, Quantitative and Mixed Methods Approaches. California: Sage Publication.

DiMaggio, P. J., \& Powell, W. W. (1983). The iron cage revisited: Institutional isomorphism and collective rationality in organizational fields. American sociological review, 147-160.

DiMaggio, P. J., \& Powell, W. W. (1991). The new institutionalism in organizational analysis (Vol. 17): University of Chicago Press Chicago, IL.

DiMaggio, P. J., \& Powell, W. W. (2000). The iron cage revisited institutional isomorphism and collective rationality in organizational fields Economics meets sociology in strategic management (pp. 143166): Emerald Group Publishing Limited.

DWI, R. (2013). Pelaporan keuangan Pemerintah Daerah di internet: Pengujian teori institusional dan keagenan. Media Ilmiah Akuntansi, 1(2), 28-48.

Feriady, M. (2019). BUSINESS STRATEGIC ANALYSIS

LEMBAGA KEUANGAN

MIKRO BERBASIS BUMDES (LKM-BUMDES) DALAM PENGUATAN EKONOMI DESA. EQUILIBRIA PENDIDIKAN: Jurnal Ilmiah Pendidikan Ekonomi, 3(2), 71-81.

Francis, J. J., Johnston, M., Robertson, C., Glidewell, L., Entwistle, V., Eccles, M. P., \& Grimshaw, J. M. (2010). What is an adequate sample size? Operationalising data saturation for theory-based interview studies. Psychology and Health, 25(10), 1229-1245.

Gibbon, J., \& Affleck, A. (2008). Social enterprise resisting social accounting: reflecting on lived experiences. Social enterprise journal.

Hayyuna, R. (2014). Strategi Manajemen Aset BUMDES Dalam Rangka Meningkatkan Pendapatan Desa (Studi pada BUMDES di Desa Sekapuk Kecamatan Ujungpangkah Kabupaten Gresik). Jurnal Administrasi Publik, 2(1), $1-5$.

Irawati, D., \& Martanti, D. E. (2018). TRANSPARANSI

PENGELOLAAN LAPORAN KEUANGAN BUMDes TERHADAP PELAPORAN ASET DESA (Studi Fenomenologi Pada BUMDes Desa Karangbendo Kec Ponggok Kab Blitar). UNEJ eProceeding, 41-51.

Kasila, M., \& Kolopaking, L. M. (2018). Partisipasi Pemuda Desa dalam Perkembangan Usaha BUMDES "TIRTA MANDIRI". Jurnal Sains Komunikasi dan Pengembangan Masyarakat [JSKPM], 2(1), 43-58.

Khairudin, \& Erlanda, R. (2016). Pengaruh Transparansi Dan Akuntabilitas Laporan Keuangan Pemerintah Daerah (LKPD) Terhadap Tingkat Korupsi Pemerintah Daerah (Studi Pada Pemerintah Kota SeSumatera). Jurnal Akuntansi \& Keuangan, 7(1), 134-157.

Mahmudah, S. (2019). AKUNTABILITAS LAPORAN KEUANGAN BADAN USAHA MILIK DESA (STUDI KASUS: BUMDES DESA SUNGON LEGOWO BUNGAH GRESIK). Ecopreneur. 12, 1(2), 32-36.

Meyer, J. W., \& Rowan, B. (1977). Institutionalized organizations: Formal structure as myth and ceremony. American journal of sociology, 83(2), 340-363.

Miles, M. B., \& Huberman, A. M. (1992). Qualitative data analysis. USA: sage. 
Mustanir, A. (2017). Partisipasi Masyarakat Dalam Musyawarah Rencana Pembangunan Di Kelurahan Kanyuara Kecamatan Watang Sidenreng Kabupaten Sidenreng Rappang. JPP (Jurnal Politik Profetik), 5(2), 247-261.

Nainggolan, A. (2016). Penganggaran Berbasis Kinerja dan Upaya Mewujudkan Good Government Governance. Jurnal Ilmiah METHONOMI, 2(1), 197033.

Nguyen, T. T., \& Van Dijk, M. A. (2012). Corruption, growth, and governance: Private vs. stateowned firms in Vietnam. Journal of Banking \& Finance, 36(11), 2935-2948.

Pillay, S. (2004). Corruption-the challenge to good governance: a South African perspective. International Journal of Public Sector Management, 17(7), 586-605.

Pratama, R. N., \& Pambudi, A. (2017). Kinerja Badan Usaha Milik Desa Panggung Lestari dalam Meningkatkan Pendapatan Asli Desa di Desa Panggungharjo Kecamatan Sewon Kabupaten Bantul. Jurnal mahasiswa Universitas Negeri Yogyakarta, 6(2), 105-116.

Putra, D. S. S., \& Mulyani, S. (2019). Manfaat Informasi Laporan Keuangan Berbasis Akrual dalam Pengambilan Keputusan. Jurnal SIKAP (Sistem Informasi, Keuangan, Auditing Dan Perpajakan), 4(1), 66-80.

Ramadana, C. B. (2013). Keberadaan Badan Usaha Milik Desa (BUMDES) sebagai Penguatan Ekonomi Desa. Jurnal Administrasi Publik, 1(6), 10681076.

Ridley-Duff, R., \& Southcombe, C. (2012). The social enterprise mark: A critical review of its conceptual dimensions. Social enterprise journal.

Ridlwan, Z. (2014). Urgensi Badan Usaha Milik Desa (BUMDes) dalam Pembangun Perekonomian Desa. Jurnal Ilmu Hukum, 8(3), 424-440.

Samadi, S., Rahman, A., \& Afrizal, A. (2015). Peranan Badan USAha Milik Desa (Bumdes) dalam Peningkatan Ekonomi Masyarakat (Studi pada Bumdes Desa Pekan Tebih Kecamatan Kepenuhan Hulu Kabupaten Rokan Hulu). Universitas Pasir Pengaraian.

Sari, R. P., Rosnita, \& Rifai, A. (2014). Analisis Kinerja Sosial dan Kinerja Keuangan Lembaga Keuangan Mikro (LKM) Usaha Ekonomi Desa-Simpan Pinjam (UED-SP) Badan Usaha Milik Desa (BUMDes) Mekar Jaya Desa Bukit Sembilan Kecamatan Bangkinang Kabupaten Kampar. Jom Faperta, 1(2), 1-13.

Sari, Y. P., \& Kismartini, K. (2016). Analisis Aktor Pembentukan Bumdes Pagedangan Cahaya Madani Dalam Perspektif Governance. Journal of Public Policy and Management Review, 1(1), 11-25.

SARI, Y. W. (2017). PRAKTIK SOSIAL KELEMBAGAAN Badan Usaha Milik Desa (BUMDes) Artha Guna di Desa Kedensari Kec. Tanggulangin Kab. Sidoarjo. Universitas Airlangga.

Sekaran, U., \& Bougie, R. (2013). Edisi 6. Research Methods for Business.

Sekaran, U., \& Bougie, R. (2016). Research methods for business: A skill building approach. New Jersey: John Wiley \& Sons.

Smith, M. (2019). Research methods in accounting: SAGE Publications Limited.

Sofyani, H., Akbar, R., \& Ferrer, R. C. (2018). 20 Years of Performance Measurement System (PMS) 
Implementation in Indonesian Local Governments: Why is Their Performance Still Poor?. Asian Journal of Business and Accounting, 11(1), 151-227.

Sofyani, H., Atmaja, R., \& Rezki, S. B. (2019). Success Factors of VillageOwned Enterprises (BUMDes) Performance in Indonesia: An Exploratory Study. Journal of Accounting and Investment, 20(2), 44-58.

Sofyani, H., Suryanto, R., Wibowo, S. A., \& Widiastuti, H. (2018). Management and Governance Practices in Dlingo Village in Bantul Regency: Learning from the Pilot Village. Jati: Jurnal Akuntansi Terapan Indonesia, 1(1), 1-16.

Suyitno. (2018). Metode penelitian kualitatif konsep, prinsip dan operasionalnya. Tulungagung: Akademia pustaka.

Thoenig, J.-C. (2012). Institutional Theories and Public Institutions: New Agendas and. The SAGE handbook of public administration, 169.

Thompson, J. L. (2008). Social enterprise and social entrepreneurship: where have we reached? Social enterprise journal.

Tolbert, P. S., \& Zucker, L. G. (1983). Institutional sources of change in the formal structure of organizations: The diffusion of civil service reform, 1880-1935. Administrative science quarterly, 22-39.

Zikmund, W. G., Babin, B. J., Carr, J. C., \& Griffin, M. (2013). Business research methods. Boston: Cengage Learning. 